\title{
DEVELOPMENT OF ANALYTICAL PROCEDURE OF DETERMINATION OF SUM OF FLAVONOIDS IN HAZELNUT (CORYLUS AVELLANA L.) POLLEN
}

\author{
Nikolaieva Nataliia ${ }^{1 *}$, Nôžková Janka' ${ }^{1}$ Hudz Nataliia ${ }^{2}$, \\ Grygorieva Olga ${ }^{3}$, Brindza Jan ${ }^{1}$
}

${ }^{1}$ Faculty of Agrobiology and Food Resourses, Slovak University of Agriculture in Nitra, Slovak Republic
2Faculty of Pharmacy, Danylo Halytsky Lviv National Medical University, Lviv, Ukraine
${ }^{3}$ M.M. Gryshko National Botanical Garden of Ukraine of National Academy of Sciences, Kyiv, Ukraine

Received 25. 6. 2017

Revised 29. 6. 2017

Published 29.11.2017

Pollen contains components necessary for growth and development of a new organism. Polyphenolic compounds are one of them. Pollen phenolic compounds are presented with flavonoids which have different structures and biological functions. Analytical procedure of spectrophotometric method was developed to determine the total flavonoids content in hazelnut (Corylus avellana L.) pollen and its methanol extracts. $0.9 \mathrm{ml} 50 \%$ ethanol was added to $0.1 \mathrm{ml}$ each extract to form volume of $1.0 \mathrm{ml}$, and then $1.0 \mathrm{~mL}$ of $2 \%$ solution of aluminum chloride hexahydrate in $50 \%$ ethanol was added. The mixture of extract was left for 70-90 minutes. As blank was a mixture which consisted of the same volumes of an extract and $50 \%$ ethanol. $1 \mathrm{ml}$ of $2 \%$ solution of aluminum chloride hexahydrate in $50 \%$ ethanol was substituted with the same volume of $50 \%$ ethanol. The curve of quercetin dihydrate was plotted in the range of its concentrations of 5.9 to $29.5 \mathrm{mg} / \mathrm{L}$. $1 \mathrm{ml}$ of the obtained solutions of quercetin dihydrate was mixed with $1.0 \mathrm{ml}$ of $2 \%$ aluminum chloride hexahydrate in $50 \%$ ethanol. The amount of $2 \%$ aluminum chloride hexahydrate in $50 \%$ ethanol was substituted by the same volume of $50 \%$ ethanol in the blank for each solution of quercetin dihydrate. The curve of rutin trihydrate was plotted in the range of its concentrations of 20.12 to $100.6 \mathrm{mg} / \mathrm{L}$. $1 \mathrm{ml}$ of the obtained solutions was mixed with $1.0 \mathrm{ml}$ of $2 \%$ aluminum chloride hexahydrate in $50 \%$ ethanol. The amount of $2 \%$ aluminum chloride hexahydrate in $50 \%$ ethanol was substituted by the same volume of $50 \%$ ethanol in the blank for each solution of rutin trihydrate. The absorbance of tested extracts and solutions of rutin was determined at $410 \mathrm{~nm}$, solutions of quercetin was determines at $425 \mathrm{~nm}$. The total flavonoid content in the tested pollen extracts was determined in the range of 133.41 to $274.23 \mathrm{mg}$ of flavonoids in $1 \mathrm{~L}$ of an extract in reference to quercetin and 418.75 to $839.32 \mathrm{mg}$ of flavonoids in $1 \mathrm{~L}$ of an extract in reference to rutin which means $3.34-6.86 \mathrm{mg}$ and $10.47-20.98 \mathrm{mg}$ per $1 \mathrm{~g}$ pollen in reference to quercetin and rutin, respectively.

Keywords: hazelnut; pollen; phenolic compounds; flavonoids; rutin; quercetin

\section{Introduction}

The chemical composition of pollen has gained worldwide research interest in the field of plant physiology and biochemistry, development of herbal food and pharmaceutical products, products on the base of beekeeper products, including dietary supplements, etc. (Leja et al., 2007; Schulte et al., 2008; Brindza and Brovarskyi, 2013; Nikolaieva et al., 2014). Pollen is rich in chemical composition because it contains components necessary for the growth and development of a new

\footnotetext{
*Corresponding author: Nataliia Nikolaieva, Faculty of Agrobiology and Food Resourses, Slovak University
} of Agriculture in Nitra, Slovak Republic, $\triangle$ n.nikolaeva703@gmail.com 
organism: proteins, lipids, carbohydrates, nucleic acids, vitamins, minerals, hormones, carotenoids, phenolic substances, etc. (Shahidi et al., 2007; Schulte et al., 2008; Aličić et al., 2014; Fatrcová-Šramková et al., 2016).

Polyphenolic compounds (mainly phenolic acids and flavonoids) are known to be present in a variety of plant tissues, including pollen. Phenolic acids and flavonoids possess antioxidant features, neutralize active oxygen species and scavenge free radicals due to their specific chemical structure and are associated with a reduced risk of various chronic diseases related with oxidation stress. Among such diseases are cardiovascular diseases, atherosclerosis, cancer, diabetes, cataracts, cognitive dysfunction and age-related function of decline, etc (Troszynska et al., 2007; Leja et al., 2007; Han et al., 2012; Fatrcová-Šramková et al., 2016). A lot of researchers indicate that antioxidant ability of pollen seems to be due to phenolic compounds. The polyphenolic content of pollen can include derivatives of phenolic acids and flavonoids that are species specific (2-5\% w/w) (Campos et al., 2008). In floral pollen phenolic compounds are mostly presented with flavonoids, their glycosides and derivatives of cinnamic acid (Leja et al., 2007). The main constituents of flavonoids are kaempferol, quercetin, luteolin and their derivatives. Specific flavonoids were identified in pollen. Among them is aglycon triacin in the Myrtaceae family (Leja et al., 2007; Negri et al., 2011). Flavonoids are pigments responsible for the flowers coloration and each type of pollen has its own specific system of flavonoids (Aličić et al., 2014). Flavonoids have different structural features and show several biological activities, in particular, they take part in light harvesting, photo protection and antioxidation of plants. Flavonoids and carotenoids are also considered as exogenous natural antioxidants for animals and people through consumption of grains, vegetables, fruits and other plants parts (Šarić et al., 2009; Han et al., 2012; Aličić et al., 2014; Fatrcová-Šramková et al., 2016).

Hazelnut (Corylus avellana L.) is considered as source for obtaining food, cosmetics and pharmaceutical products (Yurttas et al., 2000; Masullo et al., 2016; Blyznyuk et al., 2016). Hazelnut is a good source of tocopherols and nontocopherol phenolics. Among polyphenols in hazelnut were identified gallic acid, p-hydroxybenzoic acid, epicatechin and/or caffeic acid, sinapic acid, and quercetin (Yurttas et al., 2000). Five phenolic acids ( $p$-coumaric acid, caffeic acid, gallic acid, ferulic acid, and sinapic acid) were tentatively identified and quantified by Alasalvar et al. (2006) in hazelnut kernel and hazelnut green leafy cover water extracts with content of ethanol $80 \%$ (v/v) and acetone $80 \%$. Ghirardello et al. (2010) identified eight phenolic acids in hazelnut kernels: derivatives of benzoic acid (gallic, protocatechuic, 4-hydroxybenzoic, vanillic and syringic acids) and derivatives of cinnamic acid (p-coumaric, o-coumaric and sinapic acids). Hazelnut kernels contain unsaturated acids. Among non-consumed parts of this plant are leaves, bark, flowers, pollen, hard shell, green leafy cover. 12 compounds were identified in male flowers of hazel. Among them were quercetin 3-O- $\beta$-D-galactopyranosyl-

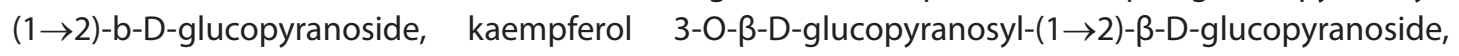
quercetin 3-O- $\beta$-D-lucopyranoside, quercetin 3-O-a-L-rhamnopyranoside, giffonin I, kaempferol 3-O-a-L-rhamnopyranoside, kaempferol 3-O-(4"-cis-p-coumaroyl)-a-L-rhamnopyranoside, alnusone, and diarylheptanoids (giffonin Q, giffonin R, giffonin S) (Alasalvar et al., 2006; Masullo et al., 2016).

The main objective of this research was to develop the approach for determination of sum of flavonoids in Corylus avellana pollen collected from trees growing in different places of the Slovak Republic. 


\section{Materials and methodology}

Samples of branches of Corylus avellana were collected in January-February 2017. Samples were prepared from different areas in Slovakia: botanical garden in Nitra (Nitra-01, Nitra-02, Nitra03, Nitra-04), village Banka (Banka-01, Banka-02, Banka-03) and village Zemianske Podhradie. They stayed at the room temperature being sunk on $5 \mathrm{~cm}$ in bottles with potable water. In 24 hours flowering began. Abundant flowering was observed in 48 hours. Pollen was collected by shaking branches. After shaking pollen was sieved and placed in aseptic tubes, which are stored in the fridge.

Pollen were put in containers, methanol was added in necessary volume and extraction was carried out at $15-25^{\circ} \mathrm{C}$ with constant shaking for 24 hours at a ratio of raw material-solvent: 1:25 (maceration). In 24 hour extracts were filtered through filter paper.

Analytical procedure of spectrophotometric method was developed to determine the total flavonoids content of hazelnut pollen in its methanol extracts (Hudz et al., 2017). $0.9 \mathrm{ml} 50 \%$ ethanol was added to $0.1 \mathrm{ml}$ each extract to form volume of $1.0 \mathrm{ml}$, and then $1.0 \mathrm{~mL}$ of $2 \%$ solution of aluminum chloride hexahydrate in $50 \%$ ethanol was added. The mixture of extract was left for 70-90 minutes. As blank was mixture which consisted of the same volumes of an extract and $50 \%$ ethanol. $1 \mathrm{ml}$ of $2 \%$ solution of Aluminum chloride hexahydrate in $50 \%$ ethanol was substituted with the same volume of $50 \%$ ethanol. The absorbance was determined at $410 \mathrm{~nm}$.

The curve of quercetin dihydrate was plotted in the range of its concentrations of 5.9 to $29.5 \mathrm{mg} / \mathrm{L}$. $1 \mathrm{ml}$ of the obtained solutions of quercetin dihydrate was mixed with $1.0 \mathrm{ml}$ of $2 \%$ aluminum chloride hexahydrate in $50 \%$ ethanol. The amount of $2 \%$ aluminum chloride hexahydrate in $50 \%$ ethanol was substituted by the same volume of $50 \%$ ethanol in the blank for each solution of quercetin dihydrate.

The curve of rutin trihydrate was plotted in the range of its concentrations of 20.12 to $100.6 \mathrm{mg} / \mathrm{L}$. $1 \mathrm{ml}$ of the obtained solutions was mixed with $1.0 \mathrm{ml}$ of $2 \%$ aluminum chloride hexahydrate in $50 \%$ ethanol. The amount of $2 \%$ aluminum chloride hexahydrate in $50 \%$ ethanol was substituted by the same volume of $50 \%$ ethanol in the blank for each solution of rutin trihydrate.

\section{Results and discussion}

Alcohol extracts of plant material are rich in flavonoids, what is more extent of extraction depends on concentration of alcohol in solvent (Шостак та ін., 2014). The absorbance of solutions with different content of quercetin dihydrate at $425 \mathrm{~nm}$ and rutin trihydrate at $410 \mathrm{~nm}$ was determined for constructing the calibration curves. Appropriate equations for calculation of sum of flavonoids in tested extracts of hazel pollen were $y_{1}=0.0276 \cdot X+0.0009$ for quercetin dihydrate $\left(R^{2}=1.0\right)$, and $y_{2}=$ $0.0095 \cdot X-0.0199\left(R^{2}=0.9952\right)$ for rutin trihydrate, where $X$ was measured in $\mathrm{mg} / \mathrm{l}$.

The results of our research with the tested extracts are presented in Table 1 and Figure 1, 2.

The total flavonoid content in the tested extracts was determined in the range of 133.41 to $274.23 \mathrm{mg}$ in $1 \mathrm{~L}$ of an extract in reference to quercetin and 418.65 to $839.32 \mathrm{mg}$ in $1 \mathrm{~L}$ of an extract in reference to rutin that means $3.34-6.86 \mathrm{mg}$ and $10.47-20.98 \mathrm{mg}$ per $1 \mathrm{~g}$ pollen in reference to quercetin and rutin, respectively. 
Table 1

Flavonoids content in $\mathrm{mg}$ in $1 \mathrm{~L}$ of the tested extracts of Corylus avellana $\mathrm{L}$. poll

\begin{tabular}{|l|c|c|}
\hline \multirow{2}{*}{ Sample origin } & \multicolumn{2}{|c|}{ Sum of flavonoids in $\mathbf{~ g / L ~ w i t h ~ r e f e r e n c e ~ t o ~}$} \\
\cline { 2 - 3 } & quercetin & rutin \\
\hline Nitra-01 & 242.4 & 743.6 \\
\hline Nitra-02 & 225.2 & 692.4 \\
\hline Nitra-03 & 274.4 & 839.2 \\
\hline Banka-01 & 201.6 & 622.8 \\
\hline Banka-02 & 248.4 & 762.0 \\
\hline Banka-03 & 146.8 & 458.4 \\
\hline Zemianske Podhradie-04 & 133.6 & 418.8 \\
\hline
\end{tabular}

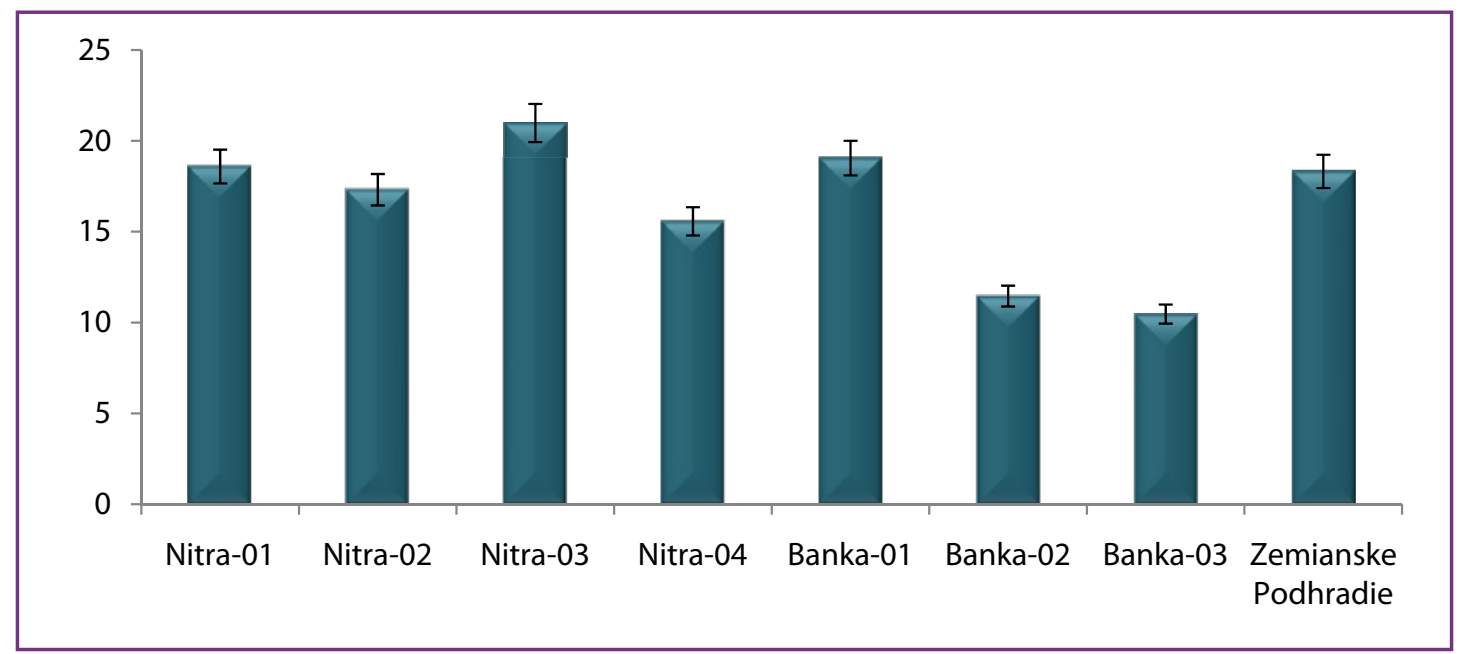

Figure 1 Sum of flavonoids in $\mathrm{mg}$ with reference to quercetin in $1 \mathrm{~g}$ of Corylus avellana L. pollen

The principle of aluminum chloride colorimetric method is that aluminum chloride forms complexes with flavons and flavonols wherein it reacts with the C-4 keto group and either the C-3 hydroxyl group of the ring $C$, and/or C-5, C-7 hydroxyl group of the ring A and the C-3' or C-4' of the ring $B$ hydroxyl groups (Chang et al., 2002). According to Chang et al. (2002), such flavonols as galangin, morin, kaemferol, rutin, quercetin, quercitrin and myrecetin have absorption maximum at 415-440 nm (ethanol in concentration of $36.5 \%$ was as medium). Our studies confirmed that absorption maximum of ethanolic solutions of quercetin was at $425 \pm 2 \mathrm{~nm}$ and ethanolic solutions of rutin was at $410 \mathrm{~nm}$.

The results of our study demonstrated that four samples from Nitra were homogenous, average sum of flavonoids and standard deviation were $(5.90 \pm 0.77) \mathrm{mg}$ in $1 \mathrm{~g}$ of pollen. Samples from Banka-01 and Zemianske Podhradie were in this range. The other two samples from Banka had significantly lower content of flavonoids. The highest and lowest levels of flavonoids were found in pollen of samples of Nitra-3 and Banka-3, respectively. In general, content of flavonoids in pollen of the tested trees of hazel was in the range of $0.334-0.686 \%$ and $1.05-2.10 \% 1 \mathrm{~g}$ pollen in reference to quercetin 
and rutin, respectively. These data are consistent with the data of Campos at al. (2008) about content derivatives of phenolic acids and flavonoids in pollen in the range of $2-5 \%(\mathrm{w} / \mathrm{w})$.

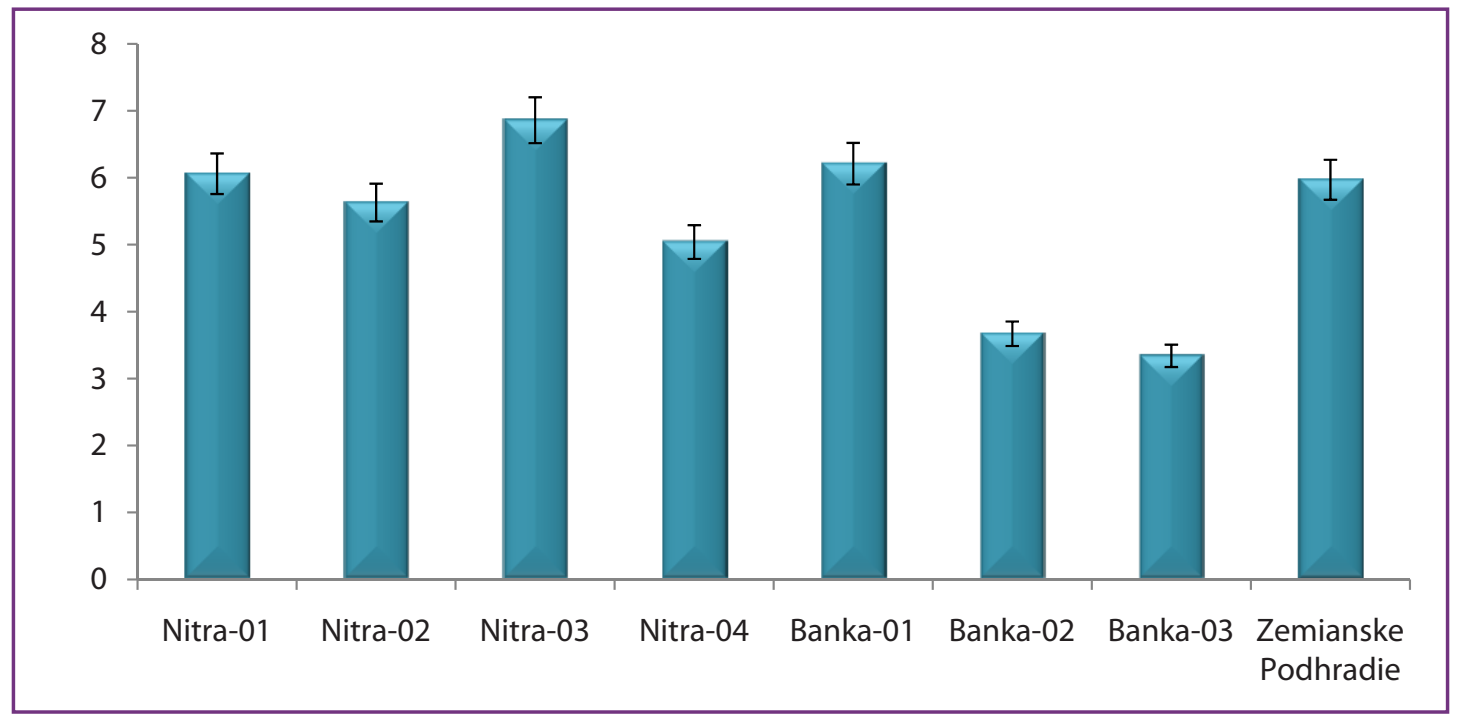

Figure 2 Sum of flavonoids in $\mathrm{mg}$ with reference to rutin in $1 \mathrm{~g}$ of Corylus avellana L. pollen

\section{Conclusions}

Procedure of the determination of flavonoids in Corylus avellana pollen were developed. It is necessary to use chromatographic studies with the purpose of confirming the correctness of the choice of analytical markers for calculation of sum of flavonoids.

\section{Acknowledgments}

The publication was prepared with the active participation of researchers involved in the International network AgroBioNet of the Institutions and researchers for realization of research, education and development program «Agrobiodiversity for improving nutrition, health and life quality» and within the project ITEBIO (ITMS 26220220115). Coauthor N. Hudz is grateful to the International Visegrad Fund for providing a scholarship for the research as experiments were conducted and this paper was created during the contracted research project (51600967).

\section{References}

Alasalvar, C., Karamac, M., Amarowicz, R., Shahidi, F. 2006. Antioxidant and antiradical activity in extracts of hazelnut kernel (Corylus avellana L.) and in hazelnut green leafy cover. Journal of Agricultural and Food Chemistry, vol. 54, no. 13, p. 4826-4832. DOI: 10.1021/jf0601259

Aličić, D., Šubarić, D., Jašić, M., Pašalić, H., Ačkar, Đ. 2014. Antioxidant properties of pollen. Hrana u zdravlju i bolesti, znanstveno-stručni časopis za nutricionizam i dijetetiku, vol. 3, no. 1, p. 6-12.

Blyznyuk, N., Prokopenko, Yu., Gergiyants, V. 2016. Development of methods for determination of phenolic acids and flavonoids in capsules containing Corylus avellana L. dry extract. Journal ScienceRise" vol. 2, 4, no. 19, p. 18-22. DOI: 10.15587/2313-8416.2016.61495

Brindza, J. Brovarskyi, V. 2013. Pollen and bee pollen of some plant species. Kyiv: Korsunskiy vidavnichiy dim «Vsesvit». 137 p. 
Campos, M.G.R., Bogdanov, S., Bicudo de Almeida-Muradian, L., Szczesna, T., Mancebo, Y., Frigerio, C., Ferreira, F. 2008. Pollen composition and standardisation of analytical methods. Journal of Apicultural Reasearch and Bee World, vol. 47, no. 2, p. 154-161. http://dx.doi.org/10.1080/00218839.2008.11101443

Chang Chia-Chia, Yang Ming-Hua, Wen Hwei-Mei and Chern Jing-Chuan. 2002. Estimation of Total Flavonoid Content in Propolis by Two Complementary Colorimetric Methods. Journal of Food and Drug Analysis, vol. 10, no. 3, p. 178-182.

Fatrcová-Šramková, K., Nôžková, J., Márriássyová, M., Kačániová, M. 2015. Biologically active antimicrobial and antioxidant substances in the Helianthus annuus L. bee pollen. Journal of Environmental Science and Health, Part B, vol. 51, no. 3, p. 176-181. DOI: 10.1080/03601234.2015.1108811.

Ghirardello, D., Prosperini, S., Scursatone, B., Gerbi, V., Zeppa, G. 2009. Identification of soluble phenolic acids in hazelnut (Corylus avellana L.) kernel. Acta Horticulturae, no. 845, p. 677-680. DOI: 10.17660/ ActaHortic.2009.845.106

Han, R.M., Zhang J.P., Skibsted, L.H. 2012. Reaction dynamics of flavonoids and carotenoids as antioxidants. Molecules, vol. 17, p. 2140-2160. DOI: 10.3390/molecules17022140.

Hudz N., Brindza J., Grygorieva O., Schubertová Z., Filipska A., Ivanišová E. 2017. Phytochemical studies of bee bread extracts. Збірник праць Х міжнародної міждисциплінарної науково-практичної конференції до 25-річчя заснування НДІ фітотерапії ДВНЗ «Ужгородський начіональний університет»: Сучасні аспекти збереження здоров'я людини, Ужгород, с. 80-83.

Leja, M., Mareczek, A., Wyżgolik G., Klepacz-Baniak, J., Czekońska, K. 2007. Antioxidative properties of bee pollen in selected plant species. Food Chemistry, vol. 100, no. p. 237-240. https://doi.org/10.1016/j. foodchem.2005.09.047

Massulo, M., Mari, A., Cerulli, A., Bottone, A., Kontek, B., Olas, B., Pizza, C., Piacente, S. 2016. Quali-quantitative analysis of the phenolic fraction of the flowers Corylus avellana, source of the Italian PGI product "Nocciola di Giffoni": Isolation of antioxidant diarylheptanoids. Phytochemistry, vol. 130, p. 273-281. https://doi.org/10.1016/j.phytochem.2016.06.007

Negri, G., Teixeira, E.W., Alves, M.L.T.M.F., Moreti, A.C., Otsuk, I.P., Borguini, R.G., Salatino, A. 2011. Hydroxycinnamic acid amide derivatives, phenolic compounds and antioxidant activities of extracts of pollen samples from Southeast Brazil. Journal of Agricultural and Food Chemistry, vol. 59, no. p. 55165522. DOI: 10.1021/jf200602k

Nikolaieva N., Grygorieva O., Brindza J., Garkava K.G., Klymenko S.V. Antioxidant activity of hazelnut (Corylus avellana L.) and sweet chestnut (Castanea sativa Mill.) pollen extracts. Scientific conference «Challenges in modern agricultural production». Scopje, Macedonia, p. 44. http://www.agricultforest. ac.me/userfiles/3\%20ANNOUNCEMENT.pdf

Šarić, A., Balog, T., Sobočanec, S., Kušić, B., Šverko, V., Rusak, G., Likić, S., Bubalo, D., Pinto, B., Reali, D., Marotti, T. 2009. Antioxidant effects of flavonoid from Croatian Cystus incanus L. rich bee pollen. Food and Chemical Toxicology, vol. 47, p. 547-554. https://doi.org/10.1016/j.fct.2008.12.007

Schulte, F., Lingott, J., Panne, U., Kneipp, J. 2008. Chemical characterization and classification of pollen. Analytical Chemistry, vol. 80, no. 24, p. 9551-9556. DOI: 10.1021/ac801791a

Shahidi, F., Alasalvar, C., Liyana-Pathirana, C. M. 2007. Antioxidant phytochemicals in hazelnut kernel (Corylus avellana L.) and in hazelnut by-products. Journal of Agricultural and Food Chemistry, vol. 55, no. 4, p. 1212-1220. DOI: 10.1021/jf062472o

Troszyńska, A., Narolewska, O., Wołejszo, A. 2007. Extracts from selected tannin-rich foods - a relation between tannins content and sensory astringency. Polish Journal of food and nutrition sciences, vol. 57 no. 3, p. 329-334.

Yurttas, H.C., Schafer, H.W., Warthesen, J.J. 2000. Antioxidant activity of nontocopherol hazelnut (Corylus spp.) phenolics. Journal of Food Science, vol. 65, no. 2, p. 276-280. DOI: 10.1111/j.1365-2621.2000.tb15993.x

Шостак, Т.А., Калинюк, Т.Г., Гудзь, Н.І. 2014. Особливості фармацевтичної розробки рослинних препаратів (Огляд літератури). Фітотерапія, Часопис, № 4, c. 77-82. http://nbuv.gov.ua/UJRN/ Fch_2014_4_23 